\title{
Blood Transfusion in Cancer Patients: Knowledge of the Nursing Team
}

Karla Fabiana Nunes da Silva1, Daniela Rosa Floriano², Rafaela Dagma Duarte ${ }^{2}$, Jordânia Lumênia Tavares ${ }^{3}$, Márcia Marques dos Santos Félix ${ }^{4}$, Quênia Cristina Gonçalves Silva ${ }^{5}$, Luana Foroni Andrade ${ }^{6}$, Lúcia Aparecida Ferreira7, Elizabeth Barichello7, Maria Helena Barbosa ${ }^{8}$

\section{Abstract}

Objectives: To assess the knowledge of nursing team professionals of a specialized hospital in oncology on transfusion practices and to identify factors associated with knowledge.

Methods: Observational, analytical, cross-sectional study held in a large and philanthropic Brazilian hospital, specialized in oncology. The unsystematic sample consisted of 61 nursing professionals who worked at the hospital. For data collection, researchers was used a validated tool of checklist type. The descriptive statistics was held in the univariate analysis and the t-test and Pearson correlation in the bivariate analysis.

Results: The average overall score of knowledge was 53.6\%; in the pre-transfusion step it was $49.6 \%$; in the transfusion step, $55.7 \%$ and in the post-transfusion step, 63.4\%. Factors associated with knowledge included the participation in specific training courses on the subject, having post-graduate degrees, the search for information in the literature, the adoption or knowledge of any standard and/ or guidelines related to the transfusion process, making use of the sector's manual of Standard Operating Procedures (SOP) and number of participation in training courses.

Conclusion: There was a general score of lack of knowledge in pre-transfusion and transfusion steps and a better understanding in the post-transfusion step. The findings reinforce the importance of
1 Master in Health Care. PhD student in the Stricto Sensu Graduate Program in Health Care, (UFTM). Uberaba (MG), Brazil.

2 Egress Nurse from the Nursing Course (UFTM). Uberaba (MG), Brazil.

3 Master in Health Care at UFTM. Uberaba (MG), Brazil.

4 Master in Health Sciences. PhD student in the Stricto Sensu Graduate Program in Health Care at UFTM. Uberaba (MG), Brazil.

5 Master in Health Care. PhD Student of the Interunidades Program of Ribeirao Preto Nursing School at EERP-USP. Ribeirao Preto (SP), Brazil.

6 Master in Physical Education. PhD student in the Stricto Sensu Graduate Program in Health Care at UFTM. Uberaba (MG), Brazil.

$7 \mathrm{PhD}$ in Nursing. Adjunct Professor of the Graduate Program in Nursing and of the Stricto Sensu Graduate Program in Health Care at UFTM. Uberaba (MG), Brazil.

$8 \mathrm{PhD}$ in Nursing in Adult Health. Associate Professor of Teaching and Scientific Department of Nursing in Hospital Care and of the Stricto Sensu Graduate Program in Health Care, (UFTM). Uberaba (MG), Brazil.

\section{Contact information:}

\section{Maria Helena Barbosa.}

Address: Av. Getúlio Guaritá, 107, Bairro Abadia, CEP: 38025-440, Uberaba (MG), Brasil.

झmhelena331@hotmail.com 
investing in periodic training and implementation of continuous and permanent education, promoting the updating of knowledge of these professionals according to the guidelines and enabling them to play safe and quality care actions.

\section{Keywords}

Knowledge; Nursing Team; Oncology; Blood Transfusion.

\section{Introduction}

The blood therapy is an important technology in modern therapy. It is one of the most effective interventions to save lives, improve the clinical condition or prognosis. Although considered a safe practice, it can cause acute and late clinical complications, in addition to a small number of adverse events when the procedure is not performed properly [1, 2].

Because it is a complex procedure, blood transfusion requires highly specialized human resources. Nursing professionals have central role in the transfusion process, which requires specific knowledge and skills to ensure the safety and efficiency of this procedure [1,3].

In cancer patients, chemotherapy often can cause hematologic toxicity, and myelotoxicity is the most important side effect because of its potential lethality. It is also worth mentioning the anemia, which is the most common complication in cancer patients, and thrombocytopenia, which makes therapeutic transfusion essential and indispensable [4].

Studies evaluating the knowledge of nursing professionals on the transfusion process demonstrated insufficient knowledge, which highlighted the need for constant evaluation and monitoring, highlighting the importance of regular training, aimed at patient safety and prevention of adverse events $[3,5,6]$.

Given the above, the objectives of this study were to evaluate the knowledge of the nursing team of a specialized hospital in oncology on transfusion practices and to identify factors associated with this knowledge.

\section{Methods}

\section{Study Characterization and ethical aspects}

This is an observational, analytical, cross-sectional study of quantitative approach of data, held in a large and philanthropic hospital, specialized in oncology, located in the region of Triangulo Mineiro, Minas Gerais, Brazil.

This study was approved by the Research Ethics Committee under Opinion No. 2434/2013 and all professionals signed the Informed Consent Form after proper guidance.

\section{Population and Sample}

In the data collection period, 217 nursing professionals were working in the hospital. The inclusion criteria were nursing professionals who provided direct care to clients in all shifts, who were employed by the institution and who were in the work schedule in the months in which data collection was performed. From these criteria, the target population (N) of this study consisted of 191 nursing professionals (Figure 1).

To calculate the sample size (n), it was considered a coefficient of positive Pearson correlation, $r=0.4$, between the length of training and the knowledge scores, to a 0.05 significance level and an 0.1 error 
Figure 1: Diagram of the population and study sample. Minas Gerais Brazil, 2015.

Nursing Team Professionals $(\mathrm{N}=217)$

Excluded professionals $(n=26)$ :

- Sick leave $(n=15)$

- Recently employed (time < 30 days) $(n=7)$

- Indirect patient care $(n=4)$

Eligible for the study according to the inclusion criteria $(N=191)$

Study sample $(n=61)$

type II, resulting in a priori power of $90 \%$. Using the Power Analysis and Sample Size (PASS) version 2002, researchers reached a minimum sample size of $n=61$.

\section{Data collection}

Authors used a validated instrument of checklist type [6], which contained questions related to professional, institutional aspects and on blood transfusion, divided into pre-transfusion step (PTS), transfusion step (TS) and post-transfusion step (POTS).

The study variables were: length of training; type of educational institution; length of work experience in the institution and in the sector; number of employment relationships; participation in specific training on blood transfusion; participation in postgraduate courses; participation in training courses and scientific events; search for information in the literature/answering questions; adoption of any standard or guideline; adoption of the Standard Operating Procedures Manual (SOP), feeling confident to carry out the transfusion process; and knowledge score about practices related to blood transfusion.

\section{Statistical analysis}

Data were entered into a Windows $X P ®$ program Excel ${ }^{\circledR}$ spreadsheet by double entry, for further vali- dation. They were then transported to the Statistical Package for Social Sciences (SPSS), version 20.0, for processing and analysis.

Initially, univariate analysis was performed, in which the qualitative variables were analyzed by using descriptive statistics, through the distribution of absolute and percentage frequency, whereas the quantitative variables were analyzed by using the descriptive measures of centrality (mean) and dispersion (standard deviation, minimum and maximum value). For bivariate analysis, contingency tables were built and it was performed comparison of central tendency measures between groups defined by categorical variables.

To calculate the knowledge score, researchers used a formula according to which the number of correctly answered items was divided by the total number of items and multiplied by one hundred.

The domains considered for the calculation of sub-score were PTS, TS and POTS.

To check whether there was a relationship between qualitative variables (related to professional aspects, to the structure and to hospital environment) and the knowledge score, the t-test was used to compare the variables with two categories, and Pearson correlation, for the quantitative variables. Statistically significant associations were those with $p \leq 0.05$; in the Pearson correlation, relations were considered weak $(0 \leq|r|<0.3)$, moderate $(0.3 \leq|r|<0.5)$ or strong $(0.5 \leq|r|<1.6)[7]$.

\section{Results}

The sample consisted of 61 nursing professionals.

The average age of professionals was 33.93 years, with a minimum of 23 and maximum of 60 years old. Regarding gender, 45 (73.8\%) were female (Table 1).

Regarding employment, 33 workers (54.1\%) had no other bonds. Among the professionals who had other employment relationships, 20 (32.8\%) had two bonds and eight (13.1\%) had three bonds. The prevailing work shift was the morning, with 24 
Table 1. Characteristics of nursing team professionals $(n=61)$.

\begin{tabular}{|l|c|c|}
\hline \multicolumn{1}{|c|}{ Variable } & N & $\%$ \\
\hline Gender & & \\
\hline Female & 45 & 73.8 \\
\hline Male & 16 & 26.2 \\
\hline Training institution & & \\
\hline Public & 10 & 16.4 \\
\hline Private & 51 & 83.6 \\
\hline Total & 61 & 100.0 \\
\hline
\end{tabular}

(39.3\%) professionals, and 53 (86.9\%) professionals reported working in a single sector of the institution (Table 2).

Table 3 shows participants' average in months of length of training, length of experience in the profession, length of working time in the institution and in the sector.
Table 2. Distribution of the number of employment bonds, work shifts and sectors of the nursing team professionals $(n=61)$.

\begin{tabular}{|l|c|c|}
\hline \multicolumn{1}{|c|}{ Variable } & N & $\%$ \\
\hline Number of employment relationships & & \\
\hline One & 33 & 54.1 \\
\hline Two & 20 & 32.8 \\
\hline Three & 8 & 13.1 \\
\hline Work shift in the institution & & \\
\hline Morning & 24 & 39.3 \\
\hline Afternoon & 10 & 16.4 \\
\hline Evening & 16 & 26.2 \\
\hline 8 hours & 7 & 11.5 \\
\hline Morning and afternoon & 4 & 6.6 \\
\hline Unit where they work & & \\
\hline A single sector & 53 & 86.9 \\
\hline More than one sector & 8 & 13.1 \\
\hline Total & 61 & 100.0 \\
\hline
\end{tabular}

Table 3. Professional characterization of the nursing team $(n=61)$.

\begin{tabular}{|l|c|c|c|c|c|}
\multicolumn{1}{|c|}{ Time } & $\begin{array}{c}\text { Mean } \\
\text { (months) }\end{array}$ & $\begin{array}{c}\text { Median } \\
\text { (months) }\end{array}$ & $\begin{array}{c}\text { SD } \\
\text { (months) }\end{array}$ & $\begin{array}{c}\text { Min. } \\
\text { (months) }\end{array}$ \\
\hline (months)
\end{tabular}

Regarding the frequency with which professionals administered transfusions, 26 (42.6\%) reported administering a monthly average of 3.67 transfusions/ month, with a minimum of zero and a maximum of 28 times/month.

As for the training or guidance offered by the institution to perform blood transfusion, 53 (86.9\%) professionals reported having received it, $34(55.7 \%)$ participated in a specific training program for blood transfusion, 21 (34.4\%) attended specific training courses for blood transfusion and only seven (11.55\%) participated in specific scientific event on blood transfusion. With regard to post-graduate courses, three $(4.9 \%)$ professionals reported having attended them, of which two
(3.3\%) professionals had specialization and one (1.6\%) had a Master's degree.

As regards the search for information in the literature, 37 (60.7\%) professionals reported seeking information or asking questions about blood transfusion.

With regard to the guidelines adopted in transfusions, 37 (60.7\%) professionals reported adopting the SOP of the sector where they work, one (1.6\%) professional adopts the Brazilian $\mathrm{MOH}$ Ordinance No. 1353 , one (1.6\%) adopts the RDC No. 153, one (1.6\%) adopts the RDC No. 57, one (1.6\%) reported adopting the Brazilian $\mathrm{MOH}$ Ordinance No. 1353 and SOP and 20 (32.9\%) do not follow or do not know any standard or guideline. 
As for confidence for performing transfusions, 58 (95.1\%) professionals reported feeling confident to conduct this procedure.

The average overall score of knowledge was $53.58 \%$, with a minimum of $20 \%$ and a maximum of $77.14 \%$. Table 4 shows the overall score and the score on the three transfusion steps.

Table 4. Knowledge scores related to blood transfusion $(n=61)$.

\begin{tabular}{|c|c|c|c|c|c|}
\hline $\begin{array}{l}\text { Frequency } \\
\text { Distribution }\end{array}$ & $\begin{array}{c}\text { Mean } \\
(\%)\end{array}$ & Median & $S D^{a}$ & $\begin{array}{l}\text { Min. } \\
(\%)\end{array}$ & $\begin{array}{l}\text { Max. } \\
\text { (\%) }\end{array}$ \\
\hline Overall score & 53.58 & 51.42 & 11.64 & 20.00 & 77.14 \\
\hline Score on PTSb & 49.64 & 42.85 & 17.61 & 14.29 & 100.00 \\
\hline Score on TSC & 55.73 & 54.16 & 11.15 & 25.00 & 79.17 \\
\hline Score on POTSd & 63.38 & 66.66 & 33.16 & 0.00 & 100.00 \\
\hline
\end{tabular}

The bivariate analysis revealed that there was statistical significance ( $p$ 0.05) between the variables participation in training courses, specific courses on blood transfusion and having post-graduation and the score in POTS $(p<0.05)$.

The search for information in the literature with the purpose of clarifying doubts had marginal significance ( $p=0.068)$ in the score on PTS. Adopting or following any standard or guideline had statistical significance $(p<0.05)$ in the overall score and in the three steps. Adopting the SOP manual of the sector showed significance $(p<0.05)$ in the score on PTS.

Table 5 shows the correlation between knowledge scores in the three stages of the transfusion process and the variables related to professional aspects.

There was correlation $(p=0.008)$ between the number of participation in specific training in blood transfusion and the score on POTS, which shows that the greater the number of participation in specific training on the subject, the greater the knowledge on post-transfusion step or on the care of transfusion complications. This correlation was characterized as moderate $(0.3 \leq|r|<0.5)$.
Table 5. Correlation between the scores on the steps of the transfusion process and professional aspects (t test) $(n=61)$.

\begin{tabular}{|c|c|c|c|c|c|c|c|c|}
\hline \multirow[t]{2}{*}{ Variables } & \multicolumn{2}{|c|}{$\begin{array}{l}\text { Overal } \\
\text { score }\end{array}$} & \multicolumn{2}{|c|}{$\begin{array}{c}\text { Score on } \\
\text { PTS }^{b}\end{array}$} & \multicolumn{2}{|c|}{$\begin{array}{c}\text { Score on } \\
\text { TSC }^{c}\end{array}$} & \multicolumn{2}{|c|}{$\begin{array}{l}\text { Score on } \\
\text { POTS }\end{array}$} \\
\hline & Mean & $S D^{a}$ & Mean & $S D^{a}$ & Mean & $S D^{a}$ & Mean & $S D^{a}$ \\
\hline \multicolumn{9}{|l|}{ Gender } \\
\hline Female & 54.41 & 11.76 & 51.42 & 17.60 & 56.66 & 11.14 & 61.48 & 33.39 \\
\hline Male & 51.25 & 11.35 & 44.64 & 17.20 & 53.12 & 11.12 & 68.75 & 33.26 \\
\hline$p$ value & \multicolumn{2}{|c|}{0.352} & \multicolumn{2}{|c|}{0.189} & \multicolumn{2}{|c|}{0.284} & \multicolumn{2}{|c|}{0.460} \\
\hline
\end{tabular}

Training institution

Public $\quad 56.28 \quad 12.12 \quad 54.28 \quad 14.75 \quad 57.91 \quad 10.1066 .66 \quad 38.49$

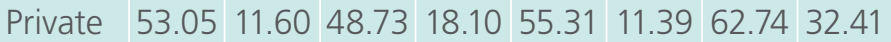
$p$ value
0.452
0.313
0.478
0.768

Other employment relationships

Yes $\quad 53.7412 .4848 .4618 .7855 .8010 .9565 .4735 .69$ No $\quad$\begin{tabular}{ll|l|l|l|l|l|l|l}
53.59 & 11.08 & 50.64 & 16.78 & 55.68 & 11.49 & 61.61 & 31.31
\end{tabular}

\begin{tabular}{|l|l|l|l|l|}
\hline$p$ value & 0.994 & 0.637 & 0.966 & 0.658 \\
\hline
\end{tabular}

Received training and guidance

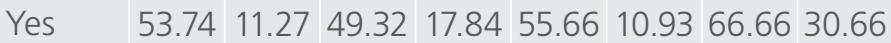
No $\quad$\begin{tabular}{lll|l|l|l|l|l}
52.50 & 14.72 & 51.78 & 16.96 & 56.25 & 13.36 & 41.66 & 42.72
\end{tabular}
$p$ value
0.824
0.713
0.908
0.149

Specific training for blood transfusions

\begin{tabular}{l|l|l|l|l|l|l|l|l} 
Yes & 54.45 & 9.82 & 49.15 & 17.29 & 56.12 & 9.90 & 71.56 & 27.37
\end{tabular} No $\quad \begin{array}{llllllll}52.48 & 13.72 & 50.26 & 18.31 & 55.24 & 12.74 & 53.08 & 32.27\end{array}$
$p$ value
0.533
0.811
0.769
$0.029 *$

Participation in specific improvement course for blood transfusions

Yes $\quad$\begin{tabular}{ll|l|l|l|l|l|l|l}
56.05 & 9.66 & 47.61 & 13.80 & 58.33 & 11.63 & 76.19 & 21.45
\end{tabular} No $\quad$\begin{tabular}{lllllll|l}
52.87 & 12.48 & 50.71 & 19.39 & 54.37 & 10.79 & 56.66 & 36.35
\end{tabular}

\begin{tabular}{|l|l|l|l|l|l}
\hline$p$ value & 0.198 & 0.519 & 0.204 & 0.028 *
\end{tabular}

Participation in specific scientific event for blood transfusions

Yes $\quad$\begin{tabular}{ll|l|l|l|l|l|l}
47.75 & 14.72 & 40.81 & 26.63 & 51.78 & 12.46 & 47.61 & 32.53
\end{tabular} No $\quad$\begin{tabular}{lll|l|l|l|l|l}
54.33 & 11.13 & 50.79 & 16.10 & 56.25 & 11.00 & 65.43 & 32.99
\end{tabular}
$p$ value
0.292
0.367
0.396
0.212

Having attended a post-graduate course

Yes $\quad$\begin{tabular}{ll|l|l|l|l|l|l}
65.71 & 13.09 & 71.42 & 28.57 & 62.50 & 11.02 & 100.0 & 0.00
\end{tabular} No $\quad \begin{array}{llllllll}52.95 & 11.34 & 48.52 & 16.48 & 55.38 & 11.14 & 61.49 & 32.92\end{array}$
$p$ value
0.230
0.299
0.380
$0.001^{*}$ 


\begin{tabular}{|c|c|c|c|c|c|c|c|c|}
\hline \multirow{2}{*}{ Variables } & \multicolumn{2}{|c|}{$\begin{array}{l}\text { Overal } \\
\text { score }\end{array}$} & \multicolumn{2}{|c|}{$\begin{array}{c}\text { Score on } \\
\text { PTS }^{b}\end{array}$} & \multicolumn{2}{|c|}{$\begin{array}{c}\text { Score on } \\
\text { TSC }^{2}\end{array}$} & \multicolumn{2}{|c|}{$\begin{array}{c}\text { Score on } \\
\text { POTS }^{d}\end{array}$} \\
\hline & Mean & $S D^{a}$ & Mean & $S D^{a}$ & Mean & $S D^{a}$ & Mean & $S D^{a}$ \\
\hline
\end{tabular}

Searching information on literature/Clarifying doubts

Yes $\quad \begin{array}{llllllll}52.74 & 10.97 & 46.33 & 17.30 & 55.74 & 11.08 & 61.26 & 31.92\end{array}$ No $\quad$\begin{tabular}{ll|l|l|l|l|l|l}
54.88 & 12.74 & 54.76 & 17.19 & 55.72 & 11.51 & 66.66 & 35.44
\end{tabular}

\begin{tabular}{|l|l|l|l|l|}
\hline$p$ value & 0.503 & $0.068 *$ & 0.996 & 0.548
\end{tabular}

Adopting or knowing any standard/guideline

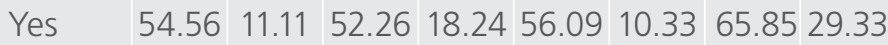
\begin{tabular}{l|l|l|l|l|l|l|l|l} 
No & 51.57 & 12.72 & 44.28 & 15.30 & 55.00 & 12.93 & 58.33 & 40.28
\end{tabular}

\begin{tabular}{|l|l|l|l|l}
\hline$p$ value & $-0.941^{*}$ & $-1.686^{*}$ & $-0.358^{*}$ & $-0.744^{*}$
\end{tabular}

Adopting SOP of the sector in transfusion practice

\begin{tabular}{lll|l|l|l|l|l|l} 
Yes & 55.18 & 11.27 & 53.75 & 18.01 & 56.35 & 10.42 & 67.54 & 29.49
\end{tabular} \begin{tabular}{l|l|l|l|l|l|l|l|l} 
No & 50.93 & 12.01 & 42.85 & 14.92 & 54.71 & 12.45 & 56.52 & 38.18
\end{tabular}
$p$ value
0.177
$0.014^{*}$
0.597
0.243

Feeling confident to perform transfusions

\begin{tabular}{lll|l|l|l|l|l|l} 
Yes & 53.79 & 10.74 & 49.50 & 16.75 & 56.03 & 10.35 & 63.79 & 32.61
\end{tabular} No $\quad 49.5227 .4552 .3835 .9550 .0025 .0055 .5550 .91$
$p$ value
0.813
0.903
0.717
0.807

a: standard deviation, b: pre-transfusion step, c: transfusion step, d: post-transfusion step, * significance values.

The other variables had no influence on the knowledge of professionals. Table 6 shows the values of $r$ and $p$ for numerical variables.

\section{Discussion}

The average age of professionals was 33.93 years, with a minimum of 23 and maximum of 60 years. This is corroborated by other Brazilian studies, in which the professionals had a mean age of 36.8 and 38.2 years, respectively $[6,8]$. In research conducted in Shahrekord, Iran, professionals were aged between 23 and 25 years [9], which shows the presence of young professionals in nursing, diverging from data found in this study.

Regarding gender, the data fond in this study was corroborated by other studies $[5,8,10]$. A study conducted at a University Hospital in Portugal also corroborates this figure, with $80.9 \%$ of female professionals [11]. An integrative review aimed to identify the factors that influenced the performance of nursing professionals in oncological units revealed that these professionals were predominantly female and aged from 30 to 40 years [12].

Regarding the type of educational institution, most graduated from private schools (83.6\%), a data that is ratified by a Brazilian study in Parana state, in which $83.6 \%$ of professionals had received their training in private institutions. This study found around $80 \%$ of growth of private nursing

Table 6. Correlation between the overall score and on the three steps and numeric variables (Pearson) $(n=61)$.

\begin{tabular}{|c|c|c|c|c|c|c|c|c|}
\hline \multirow{2}{*}{ Variables } & \multicolumn{2}{|c|}{ Overal score } & \multicolumn{2}{|c|}{ Score on PTSb } & \multicolumn{2}{|c|}{ Score on TSC } & \multicolumn{2}{|c|}{ Score on POTSd } \\
\hline & $r$ & $p^{a}$ & $r$ & $p^{a}$ & $r$ & $p^{a}$ & $r$ & $p^{a}$ \\
\hline $\begin{array}{l}\text { Number of blood transfusions } \\
\text { performed/month }\end{array}$ & 0.012 & 0.926 & -0.065 & 0.618 & 0.031 & 0.812 & 0.047 & 0.719 \\
\hline Length of training & 0.053 & 0.683 & 0.124 & 0.340 & 0.013 & 0.921 & 0.030 & 0.821 \\
\hline Length of professional experience & 0.075 & 0.565 & 0.119 & 0.362 & 0.009 & 0.944 & 0.136 & 0.295 \\
\hline $\begin{array}{l}\text { Length of working time in the } \\
\text { institution }\end{array}$ & 0.092 & 0.479 & 0.074 & 0.572 & 0.051 & 0.694 & 0.148 & 0.254 \\
\hline $\begin{array}{l}\text { Length of working time in the } \\
\text { sector }\end{array}$ & 0.044 & 0.735 & 0.042 & 0.746 & 0.062 & 0.632 & -0.039 & 0.764 \\
\hline $\begin{array}{l}\text { Number of employment } \\
\text { relationships }\end{array}$ & -0.041 & 0.755 & -0.059 & 0.653 & -0.040 & 0.761 & 0.013 & 0.923 \\
\hline $\begin{array}{l}\text { Number of participation in specific } \\
\text { training }\end{array}$ & 0.069 & 0.597 & -0.137 & 0.293 & 0.043 & 0.740 & 0.336 & $0.008 *$ \\
\hline
\end{tabular}


courses/schools, which automatically generates a considerable increase in the number of professionals in the labor market coming from these institutions [13]. The results of this research can also be supported by a descriptive exploratory study on nursing courses in Minas Gerais, which showed that most of the courses focuses on privatized teaching [14].

In contrast, research conducted in a teaching hospital in Minas Gerais noted that the majority of nurses $(60.0 \%)$ received their training in public institutions [5].

Regarding length of training, length of professional experience, of working time in the institution and of working time in the sector, Brazilian studies confirm these findings, since most professionals had had more than five years of professional experience $[5,8]$. Diverging from these results, another Brazilian study conducted in a Teaching Hospital of Triangulo Mineiro noted that professionals had a mean of 144.25 months of training, 147.07 months of professional experience, 117.73 months of work in the studied institution and mean of 80.74 months of work in the sector [6]. Another survey of nurses in Portugal identified mean of 13 years of professional experience [11].

For nurses, the obtainment of professional experience during the management of their staff and the provision of direct patient care are factors that contribute to the improvement of specific skills and autonomy in decision-making [15].

About employment bonds, a study in an oncohematology child hospital of Campinas corroborates the findings of this research, in which much of the professionals had two or more bonds [16].

Regarding the frequency with which professionals administer transfusions, there was an average of 3.67 transfusions/month. A study conducted in four public and university hospitals in Jordan showed that, during six months prior to data collection, the professionals performed blood transfusions at a frequency ranging from one to four times/month and it could reach 12 times, which corroborates the data of this study [17]. In other studies, it was observed that the nursing professionals performed blood transfusion once in a week [8, 10].

Regarding the training or guidance offered by the institution to perform blood transfusion, most professionals claimed to have received this guidance and participated in some specific training program. A study conducted in the ICU of a university hospital in Minas Gerais showed that $89.0 \%$ of the respondents reported having received information about the transfusion process [5]. Unlike the results, studies conducted with nurses in Jordan and Mali, in West Africa, revealed that the majority (92.4\% and $70.9 \%$, respectively) had never received any training on the subject since their graduation $[17,18]$.

Concerning the participation on specific training courses for care in hemotherapy, 34.4\% of the professionals have done it and $11.5 \%$ participated in specific scientific event. Corroborating the findings, a study conducted in the ICU of a university hospital revealed that $39.0 \%$ of surveyed professionals reported having participated in updating courses and $16.0 \%$ in training courses [5].

As for the search for information in the literature and the adoption of standards that guide the transfusion practice, a study in a Teaching Hospital that assessed knowledge about blood transfusion found that $73.7 \%$ of professionals said they seek information and $73.2 \%$ of the professionals mentioned adopting the institutional SOP manual in their practice [6]. However, in another study, showed that $92.4 \%$ of nurses say they have never received any kind of training on blood transfusion and 33\% reported that there is a need to acquire such training [17]. In Brazilian research conducted in a hospital in Rio Grande do Norte, $82.5 \%$ of professionals reported ignoring the current resolution, diverging from the present study findings [10].

The SOP establishes the standardization of procedures and allows all workers to provide care in a 
standardized manner and within the scientific and technical principles, contributing to extinguish the distortions acquired in practice. In this sense, it has also an educational purpose [19].

Related to the confidence to perform transfusions, the majority reported feeling confident during the procedure, as ratified by a study which shows that $92.8 \%$ of the respondents feel confident for conducting the procedure [6].

Concerning to post-graduation, $4.9 \%$ of the professionals had it, of which $3.3 \%$ had specialization and $1.6 \%$ has Master's degree. Studies in a University Hospital in Rio Grande do Norte and Minas Gerais differ from these results, in which 18.5\% and $27.8 \%$ of the professionals had post-graduate degrees, respectively $[6,10]$.

Concerning the nursing staff's knowledge on blood transfusion, there was low overall score (53.6\%), ranging from $20.0 \%$ to $77.1 \%$. Studies support the findings of this research and show that $53.9 \%$ of participants had insufficient knowledge [18]. A study conducted in Iran noted insufficient knowledge with scores ranging from $59.0 \%$ to $66.7 \%$ [9]. In another survey, confirmed deficiency in relation to knowledge about blood transfusion, with scores between 27 and 56\%, averaging $40.8 \%$ [3].

It was shown in this study greater deficit in pre-transfusion and transfusion steps, with an average score of $49.6 \%$ and $55.7 \%$, respectively. A study conducted in a teaching hospital of Triangulo Mineiro corroborates these results, which showed an average score of $53.58 \%$ on pre-transfusion step and $51.25 \%$ on the transfusion step [6]. In contrast, another study conducted in the ICU of a university hospital in Rio Grande do Norte identified a more adequate knowledge on the pre-transfusion and transfusion steps and inappropriate knowledge on procedures related to the post-transfusion step [10].

Concerning the post-transfusion step, the knowledge score was $63.4 \%$, with a minimum of zero and a maximum of $100.0 \%$, which shows a better understanding on the immediate transfusion complications, recognition of signs and symptoms and nursing care. Corroborating this fact, a study conducted in a city of Triangulo Mineiro showed a score of $62.7 \%$ in the step related to transfusion complications [6]. In contrast, a study conducted in the ICU of a hospital in Natal-RN observed greater inadequacy in care for transfusion reactions (62.9\%) [10].

Study conducted in Namibia showed that 96\% of the professionals were able to identify an acute transfusion reaction, 74\% were aware of the blood vigilance system and the importance of reporting; however, 5\% have correctly identified the signs and symptoms of a transfusion reaction [20].

The bivariate analysis evidenced the influence of factors on the knowledge score, such as participation in training and specific training courses on the subject, having post-graduate degrees, searching information in the literature, adopting or knowing any standard and/or guideline related to transfusion process, making use of SOP manual of the sector and the number of participations in training courses. Corroborating the data, study in a teaching hospital of Triangulo Mineiro showed relationship between the variables: being a nurse, attending specific training for blood transfusion, having post-graduate degree, knowing or adopting any standard, and the knowledge scores [6].

An integrative review conducted to identify the profile of nurses in oncology hospitals revealed the need to search for professional development through specialization, post-graduation, residency programs, training courses, updating courses and conferences [15].

The development of care protocols and routines to organize the care of the nursing professionals to the patient revitalizes and motivates these workers, making them more confident and aware of the work process, thus reflecting in a quality and safe care [21]. 
A limitation of this study, considering the chosen method, was the non-monitoring of transfusion steps, but this did not jeopardize the achievement of the proposed objectives and enabled the presentation of relevant data to the theme. It is suggested to carry out prospective studies in the area, including the systematic observation of transfusions.

\section{Conclusion}

This study has highlighted a low overall knowledge score in pre-transfusion and transfusion steps, and a better understanding of post-transfusion step, that is, in the step related to the immediate transfusion complications.

Factors influencing knowledge about blood transfusion were participating in training and specific course on blood transfusion, having post-graduate degree, seeking information in the literature, adopting or knowing any standard or guideline on blood transfusion and adopting the SOP manual of the institution as standard or guideline, and the number of participations in specific training on the subject.

Given these findings, authors emphasize the importance of investment in periodic training and implementation of continuous and permanent education with the purpose of updating the knowledge of these professionals according to the regulations, enabling them to perform safe and quality care actions.

This research highlights the need for a critical and reflective performance by the nursing professionals and the importance of improving knowledge in the light of scientific evidence with the goal of providing excellent and safe care in complex procedures.

\section{Acknowledgements}

The authors thank the Foundation for Research of the State of Minas Gerais (FAPEMIG) and the National Council for Scientific and Technological Development (CNPq) for financial support.

\section{Conflict of interest}

The authors have no conflict of interest to be disclosed.

\section{References}

1. Brasil. Secretaria de Atenção a Saúde. Departamento de Atenção Especializada. Guia para o uso de hemocomponentes. Brasília: Editora do Ministério da Saúde; 2010.

2. Flores-Torrecillas R, Carballo-Monreal MR, Alvarez-Villaseñor AS, ValdezMárquez ML, González-Ojeda A, Fuentes-Orozco C. Manejo y administración de hemoderivados por personal de enfermería en un hospital de segundo nivel. Enferm. Univ. [Internet]. 2014 Sep [cited 2016 aug 10]; 11(3): 94-100. Available from: http://www.revistas.unam.mx/index.php/reu/article/ view/47586/42810.

3. Hijji B, Parahoo K, Hussein MM, Barr O. Knowledge of blood transfusion among nurses. J Clin Nurs. 2013; 22 (17-18): 25362550.

4. Freitas JV, Almeida PC, Guedes MVC. Perfil das reações transfusionais em pacientes pediátricos oncológicos. Rev enferm UFPE on line. 2014; 8(9): 3030-3038.

5. Silva KFN, Soares S, Iwamoto $\mathrm{HH}$. A prática transfusional e a formação dos profissionais de saúde. Rev. Bras. Hematol. Hemoter. [Internet]. 2009 [cited 2016 fev 22]; 31(6): 421-426. Available from: http://www.scielo.br/scielo.php?script=sci arttext\&pid=S1516-84842009000600009\&lng=en.

6. Tavares JL, Barichello E, De Mattia AL, Barbosa MH. Fatores associados ao conhecimento da equipe de enfermagem de um hospital de ensino sobre hemotransfusão. Rev. Latino-Am. Enfermagem [Internet]. 2015 Aug [cited 2016 fev 17]; 23(4): 595602. Available from: http://www.scielo.br/scielo.php?script=sci arttext\&pid=S0104-11692015000400595\&lng=en

7. Cohen J. Statistical power analysis for the behavioral sciences. 2 ed. Mahwah. Lawrence Earlbaum; 1988.

8. Ferreira O, Martinez EZ, Mota CA, Silva AM. Avaliação do conhecimento sobre hemoterapia e segurança transfusional de profissionais de enfermagem. Rev. Bras. Hematol. Hemoter. [Internet]. 2007 June [cited 2016 aug 10]; 29(2): 160-167. Available from: http://www.scielo.br/scielo.php?script=sci arttext\&pid=S1516-84842007000200015\&lng=pt

9. Aslani Y, Etemadyfar S, Noryan K. Nurses' knowledge of blood transfusion in medical training centers of Shahrekord University of Medical Science in 2004. Iran J Nurs Midwifery Res. [Internet]. 2010 [cited 2016 jun 23]; 15(3): 141-144. Available: https:// www.ncbi.nlm.nih.gov/pmc/articles/PMC3093170/ 
10. Silva MA, Torres GV, Melo GSM, Costa IKF, Tiburcio MP, Farias TYA. Conhecimento acerca do processo transfusional da equipe de enfermagem da UTI de um hospital universitário. Ciênc. cuid. Saúde [Internet]. 2009 Out/Dez [cited 2016 fev 10]; 8(4): 571 578. Available from: http://periodicos.uem.br/ojs/index.php/ CiencCuidSaude/article/view/9676/5389

11. Freixo A, Matos I, Leite A, Silva A, Bischoff F, Carvalho M, et al. Nurses knowledge in Transfusion Medicine in a Portuguese university hospital: the impact of an education. Blood Transfus. [Internet]. 2016 [cited 2016 jul 18]; 19:1-4. Available from: http:// www.bloodtransfusion.it/scarica.aspx?tipo $=$ P\&id $=000796$

12. Hercos TM, Vieira FS, Oliveira MS, Buetto LS, Shimura CMN, Sonobe HM. O trabalho dos profissionais de enfermagem em Unidades de Terapia Intensiva na assistência ao paciente oncológico. Rev. bras. cancerol. [Internet]. 2014 [cited 2016 aug 10]; 60(1): 51-58. Available from: http://www.inca.gov. br/rbc/n 60/v01/pdf/08-revisao-literatura-o-trabalho-dosprofissionais-de-enfermagem-em-unidades-de-terapiaintensiva-na-assistencia-ao-paciente-oncologico.pdf

13. Rodrigues RM, Caldeira S. Formação na graduação em enfermagem no Estado do Paraná. Rev. bras. enferm. [Internet]. 2009 June [cited 2016 aug 10]; 62(3): 417-423. Available from: http://www.scielo.br/scielo.php?script=sci_arttext\&pid=S003471672009000300013\&lng=en

14. Silva KL, Sena RR, Tavares TS, Maas LW. Expansão dos cursos de Graduação em Enfermagem e mercado de trabalho: reproduzindo desigualdades? Rev. bras. enferm. [Internet]. 2012 June [cited 2016 fev 10]; 65(3): 406-413. Available from: http://www.scielo.br/scielo.php?script=sci arttext\&pid=S0034$71672012000300003 \& \operatorname{lng}=$ en.

15. Santos FC, Camelo SHH, Laus AM, Leal LA. O enfermeiro que atua em unidades hospitalares oncológicas: perfil e capacitação profissional. Enfermería Global [Internet]. 2015 [cited $2016 \mathrm{fev}$ 10]; 14(38): 313-324. Available from: http://scielo.isciii.es/pdf/ eg/v14n38/pt revision3.pdf

16. Zanatta $A B$, Lucca SR. Prevalência da síndrome de burnout em profissionais da saúde de um hospital oncohematológico infantil. Rev. esc. enferm. USP [Internet]. 2015 [cited 2016 fev 17]; 49(2): 253-260. Available from: http://www.scielo.br/pdf/ reeusp/v49n2/pt 0080-6234-reeusp-49-02-0253.pdf

17. Hijji BM, Oweis AE, Dabbour RS. Measuring knowledge of blood transfusion: a survey of Jordanian nurses. Am Int J Contemp Res. [Internet]. 2012 Oct [cited 2016 jul 18]; 2(10): 7779. Available from: http://www.aijcrnet.com/journals/Vol 2 No_10_October_2012/10.pdf

18. Diakité M, Diawara SI, Tchogang NT. Knowledge and attitudes of medical personnel in blood transfusion in Bamako, Mali. Transfus Clin Biol. 2012; 19(2): 74-77.
19. Almeida ML de, Segui MLH, Maftum MA, Labronici LM, Peres AM. Instrumentos gerenciais utilizados na tomada de decisão do enfermeiro no contexto hospitalar. Texto contexto - enferm. [Internet]. 2011 [cited 2016 jun 20]; 20(spe): 131-137. Available from: http://www.scielo.br/scielo.php?script=sci arttext\&pid=S0104-07072011000500017\&lng=pt

20. Basavaraju SV, Britta Lohrke B, Pitman JP, Pathak SR, Meza BPL, Shiraishi RW, et al. Knowledge and barriers related to reporting of acute transfusion reactions among healthcare workers in Namibia. Transf Med. [Internet]. 2013 Oct [cited 2016 jul 01]; 23(5): 367-369. Available from: https://www.ncbi.nlm.nih.gov/ pmc/articles/PMC4597892/

21. Gonçalves ACS, Said FA. No processo de educação continuada, a construção de um protocolo assistencial de enfermagem à terapia transfusional: relato de experiência. Revista Eletrônica da Faculdade Evangélica do Paraná. [Internet]. 2011 [cited 2016 jul 18]; 1(2): 12-30. Available from: http://www.fepar.edu.br/ revistaeletronica/index.php/revfepar/article/view/22/35.

\section{Publish in International Archives of Medicine}

International Archives of Medicine is an open access journal publishing articles encompassing all aspects of medical science and clinical practice. IAM is considered a megajournal with independent sections on all areas of medicine. IAM is a really international journal with authors and board members from all around the world. The journal is widely indexed and classified Q2 in category Medicine. 